\title{
Penerapan Gerakan Karakter Sejuk Emosi, Hati, Akal, dan Tubuh (SEHAT) untuk Meningkatkan Motivasi Belajar Mahasiswa Diploma III Kebidanan
}

\author{
Endang Susilowati, ${ }^{1}$ Nanan Sekarwana, ${ }^{2}$ Herman Susanto, ${ }^{3}$ Farid Husin,,${ }^{4}$ Firman F. Wirakusumah, ${ }^{5}$ \\ Juntika Nurihsan, ${ }^{6}$ \\ ${ }^{1}$ Mahasiswa Program Studi Magister Kebidanan Fakultas Kedokteran Universitas Padjadjaran \\ ${ }^{2}$ Departemen Ilmu Kesehatan Anak Fakultas Kedokteran Universitas Padjadjaran \\ ${ }^{3}$ Departemen Obstetri dan Ginekologi Fakultas Kedokteran Universitas Padjadjaran \\ ${ }^{4}$ Departemen Epidemiologi dan Biostatistika Fakultas Kedokteran Universitas Padjadjaran \\ ${ }^{5}$ Departemen Obstetri dan Ginekologi Fakultas Kedokteran Universitas Padjadjaran \\ ${ }^{6}$ Program Studi Psikologi Pendidikan Sekolah Pascasarjana Universitas Pendidikan Indonesia
}

\begin{abstract}
Abstrak
Berdasarkan kajian literatur, survei, dan pengalaman di lapangan, pelayanan kebidanan belum sesuai dengan harapan. Salah satu penyebabnya adalah karakter yang dimiliki bidan belum maksimal terinternalisasi dalam kehidupan sehari-hari. Pendidikan karakter diyakini memiliki dampak yang besar dalam menumbuhkan nilai-nilai karakter dalam diri seseorang. Gerakan Karakter Sejuk, Emosi, Hati, Akal, dan Tubuh (SEHAT) merupakan upaya menggerakkan civitas akademika dalam menanamkan nilai-nilai karakter yang baik berdasarkan kesejukan emosi, hati, akal, dan tubuh melalui gerakan pengungkapan nilai karakter, gerakan disiplin kampus, gerakan artikel dinding, gerakan olahraga, dan gerakan metamorfosa. Nilai karakter yang dikembangkan adalah mandiri, tanggung jawab, kreatif, kerja keras, dan menghargai prestasi. Rancangan penelitian yang digunakan adalah action research dengan pre-post test design. Penelitian dilaksanakan selama 12 minggu, dengan masing-masing siklus selama 4 minggu. Populasinya adalah mahasiswa Diploma III Kebidanan Semester III Akademi Kebidanan (Akbid) Panti Wilasa YAKKUM Semarang dan Akbid Ar Rum Salatiga dengan jumlah 62 orang, menggunakan total populasi. Analisis data untuk nilai karakter mandiri, tanggung jawab, kreatif, kerja keras, menghargai prestasi, dan motivasi belajar dilakukan dengan uji $\mathrm{T}$ berpasangan dan uji Wilcoxon, sedangkan pengujian hipotesisnya dengan uji Korelasi Pearson dan Spearman rho. Hasil penelitian menunjukkan penerapan gerakan karakter "SEHAT" meningkatan nilai karakter mandiri, tanggung jawab, kreatif, kerja keras, dan menghargai prestasi $(\mathrm{p}<0,001)$. Penerapan gerakan karakter "SEHAT" meningkatkan motivasi belajar $(\mathrm{p}<0,001)$. Terdapat korelasi positif antara nilai karakter mandiri $(\mathrm{p}=0,005)$, tanggung jawab $(p<0,001)$, kreatif $(p=0,003)$, kerja keras $(p=0,003)$, menghargai prestasi $(p<0,001)$ dengan motivasi belajar. Simpulan hasil penelitian, penerapan gerakan karakter "SEHAT" meningkatkan nilai mandiri, tanggung jawab, kreatif, kerja keras, menghargai prestasi, dan motivasi belajar mahasiswa serta terdapat korelasi positif.
\end{abstract}

Kata Kunci: Gerakan Karakter "SEHAT", motivasi belajar 


\title{
Implementation Movement Emotions of Cool Character, Heart, Mind , and Body (HEALTHY ) to Improve Student Motivation Learning in Midwifery Diploma
}

\begin{abstract}
Based on the literature review, surveys and experience in the field, the obstetric care remains not in line with the expectations. One reason is the character owned by a midwife is not maximally internalized in the daily life. Character education is believed to have a major impact in fostering the values of a person's character. The Character Movement of "SEHAT" is an effort to motivate the academic faculty in internalizing the values of noble character based on the coolness of emotion, heart, mind and body, through the disclosure movement of the value of the character, the movement of campus discipline, the movement of the wall article, by the excercise movement, and the movement of metamorphosi. Values characters are developed independently, responsibility, creativity, hard work and reward achievement. With this research the students learning motivation could be hopefully improved. The design of this study was Action Research with pre-post test design. The study lasted 12 weeks, with each cycle for 4 weeks. The population was the students of Diploma in Midwifery Semester III Akbid Panti Wilasa YAKKUM Semarang and Akbid Ar Rum Salatiga, 62 in number, using total population. Data analysis of character value independently, responsibility, creativity, hard work, reward achievement, and learning motivation was the paired test and Wilcoxon, while hypothesis testing was Pearson and Spearman rho. The results showed that was carried out by The Character Movement of "SEHAT" increase the value of an independent character, responsibility, creativity, hard work, and appreciate the achievements $(\mathrm{p}=0.000)$. The Character Movement of "SEHAT" increase of learning motivation $(\mathrm{p}=0.000)$. There was a positive correlation between the value of an independent character $(p=0,005)$, responsibility $(p=0,000)$, creativity $(\mathrm{p}=0,003)$, hard work $(\mathrm{p}=0,003)$, appreciate the achievements $(\mathrm{p}=0,000)$ with the learning motivation. As the conclusion of the results of the study, the application of Character Movement "SEHAT" increases the value of an independent character, responsibility, creativity, hard work, appreciate the achievement, the learning motivation of the students and there was a positive correlation.
\end{abstract}

Keywords: Character Movement "SEHAT", learning motivation.

\section{Pendahuluan}

Permasalahan yang terjadi saat ini menunjukkan bahwa kebanyakan bidan hanya mengandalkan pelayanan yang bersifat hard skill saja. Salah satu contoh kasus adalah pengaduan pasien/keluarga terhadap petugas kesehatan di Unit Rawat Inap Kebidanan RSUD Dr. H. Soemarno Sosroatmojo, Bulungan, Kalimantan Timur. Pada tahun 2009 disebutkan petugas kesehatan di rumah sakit tersebut (termasuk di dalamnya adalah bidan), memiliki nilai kurang dalam hal kepedulian, sikap dalam pelayanan, kebersihan, keandalan, dan kecepatan. ${ }^{1}$ Kinerja bidan dalam program Jaminan Pemeliharaan Kesehatan Masyarakat Miskin di desa masih kurang, yaitu 56,5\% (59 orang) dan $71,2 \%$ (74 orang) bidan di desa berdomisili di luar desa tempatnya bertugas. ${ }^{2}$ Dikatakan bahwa di dalam memberikan pertolongan persalinan bidan kurang sabar, bidan tidak siaga di kliniknya (sering bepergian keluar desa), tidak mampu beradaptasi dengan lingkungan, dan ada pula suami bidan tidak mengizinkan istrinya untuk pergi keluar pada malam hari untuk menolong persalinan. ${ }^{3}$ Berdasarkan pernyataan dukun bayi di Kabupaten Madiun pada saat menunggu persalinan, bidan tidak mampu terjaga sampai proses kala II, tetapi memilih tidur dan minta dibangunkan apabila pasien sudah akan melahirkan. ${ }^{4}$ Dari studi pendahuluan yang dilakukan pada Dinas Kesehatan, Kepala Puskesmas, Bidan Koordinator, dan masyarakat di Kota Semarang dan Kabupaten Semarang masih ditemukan permasalahan karakter bidan di antaranya adalah disiplin waktu, tanggung jawab, peduli lingkungan, komunikasi/ bersahabat, toleransi, sopan, rasa ingin tahu, 
jujur, mandiri, kerja keras, peduli sosial, dan kreatif. $^{5}$

Berdasarkan fakta tersebut di atas, institusi pendidikan kebidanan memiliki tanggung jawab yang besar untuk menghasilkan bidan yang berkualitas, baik kompetensi maupun karakternya sesuai dengan harapan masyarakat. Potret suasana akademik di institusi pendidikan kebidanan sekarang ini menunjukkan masih ada permasalahan yang terkait karakter. Dari studi pendahuluan yang dilakukan pada 62 intitusi kebidanan di Indonesia, dari 90 responden masih ditemukan permasalahan terkait dengan karakter, di antaranya komunikasi antar dosen yang kurang baik, persaingan yang tidak sehat, tidak menepati janji, terlambat masuk kantor, dan melakukan sikap yang memicu timbulnya perselisihan dan perkelahian. Ada pula permasalahan antara dosen dengan mahasiswa, di antaranya tidak menepati janji dan kurangnya kepedulian sosial. Hubungan antara dosen dan tenaga kependidikan juga menunjukkan rendahnya penghayatan nilainilai karakter, di antaranya tidak menepati janji, dan memicu timbulnya perselisihan dan perkelahian. $^{5}$

Melihat potret permasalahan di atas (masalah di dalam institusi pendidikan kebidanan, keadaaan bidan, dan kebutuhan masyarakat terkait pelayanan kebidanan) penerapan nilai-nilai karakter dalam institusi pendidikan kebidanan menjadi kebutuhan yang mendesak. Selain untuk menjawab tuntutan pelayanan bidan, penanaman nilainilai karakter memiliki dampak juga dalam proses pendidikan diantaranya adalah motivasi belajar. Penghayatan nilai-nilai karakter yang baik menjadikan mahasiswa mampu memberikan keputusan yang baik dan menjadi pribadi yang memiliki integritas.

Motivasi belajar memberikan peran dalam hal menumbuhkan semangat, perasaan senang, dan keinginan untuk melakukan segala hal, khususnya adalah belajar. Mahasiswa yang memiliki motivasi yang kuat dapat dipastikan memiliki energi untuk melakukan kegiatan belajar., ${ }^{6,7}$ Motivasi belajar mendorong mahasiswa memiliki semangat dalam mencapai tujuannya. ${ }^{8,9}$ Apabila suasana akademik bermasalah/tidak kondusif dalam proses pembelajaran, dapat dipastikan akan menurunkan motivasi belajar mahasiswa. Dalam teori perilaku memandang motivasi sebagai suatu perubahan perilaku (respon), perilaku melibatkan diri dalam tugas-tugas, bersikap gigih pada saat pengerjaan tugas, dan selalu berusaha merupakan penilaian yang dapat dilakukan oleh dosen dalam menilai peserta didik. Selain itu, adanya motivasi intrinsik dan ekstrinsik memiliki pengaruh yang besar dalam menumbuhkan motivasi belajar peserta didik. $^{6,10}$

Mahasiswa yang memiliki motivasi belajar yang rendah menunjukkan perilaku kurang baik, antara lain terlambat masuk kelas, terlambat dalam menyelesaikan tugas, bersikap pasif pada saat proses pembelajaran berlangsung, kurang fokus dan konsentrasi, kontrol diri yang kurang, misalnya berbicara dengan teman yang duduk di sebelahnya pada saat proses pembelajaran sehingga hasil belajarnya pun tidak optimal. Belajar mandiri belum menjadi budaya mahasiswa, belajar dengan sungguh hanya dilakukan pada saat mendekati ujian. Mahasiswa belum dapat memanfaatkan waktu untuk belajar secara mandiri pada saat jam kosong.

Penelitian yang dilakukan oleh Marvin Berkowitz (University of Missouri-St.Louis), menunjukkan adanya peningkatan prestasi akademik siswa pada sekolah-sekolah yang menerapkan pendidikan karakter, serta didukung adanya peningkatan motivasi intrinsik dan ekstrinsik siswa. Kelas-kelas yang secara komprehensif terlibat di dalam pendidikan karakter menunjukkan terjadinya penurunan perilaku negatif siswa yang dapat menghambat keberhasilan akademik/ prestasi akademik. ${ }^{11}$ Siswa memiliki motivasi lebih baik untuk belajar dan memiliki hubungan yang dekat dengan sekolah. ${ }^{12}$

Berbagai macam cara dapat dilakukan untuk menumbuhkan dan meningkatkan motivasi belajar mahasiswa misalnya dengan memberikan bimbingan, hadiah, hukuman, pemberian pujian, mengadakan kompetisi, memberikan tugas, dan lain sebagainya. Dalam rencana penelitian ini cara yang dipakai untuk menumbuhkan karakter mahasiswa, dan motivasi belajar adalah dengan gerakan karakter "SEHAT" yang mampu mencakup semua cara dalam menumbuhkan karakter dan motivasi belajar mahasiswa. Gerakan karakter "SEHAT" 
memiliki dasar dari konfigurasi pendidikan karakter, olah hati, olah pikir, olah rasa/karsa, dan olah raga dengan harapan menjawab permasalahan yang ada.

Diawali dengan kegiatan workshop untuk dosen dan tenaga kependidikan tentang pentingnya karakter seseorang memengaruhi setiap aspek kehidupan termasuk dalam bekerja dan belajar serta sebagai awal komitmen pelaksanaan gerakan karakter "SEHAT". Gerakan karakter "SEHAT" merupakan satu pohon penelitian untuk menilai karakter yang dilaksanakan di pendidikan kebidanan dengan 5 (lima) gerakan sebagai permulaannya, yaitu gerakan pengungkapan nilai karakter, gerakan disiplin kampus, gerakan artikel dinding, gerakan olahraga, dan gerakan metamorfosa yang dilaksanakan oleh seluruh civitas akademik termasuk dosen dan tenaga kependidikan. Harapannya dengan gerakan karakter "SEHAT" dapat meningkatkan seluruh aspek nilai karakter mahasiswa dalam meningkatkan motivasi belajar.

\section{Metode}

\section{Populasi dan Sampel}

Populasi dalam penelitian ini adalah seluruh mahasiswa Diploma III Kebidanan Semester III Akademi Kebidanan Panti Wilasa YAKKUM Semarang dan Akademi Kebidanan Ar Rum Salatiga dengan jumlah 62 mahasiswa yang mendapatkan gerakan karakter "SEHAT". Sampel dalam penelitian ini menggunakan total populasi.

\section{Kriteria Inklusi dan Eksklusi} adalah:

Kriteria inklusi dalam penelitian ini

1. Mahasiswa Diploma III Kebidanan Tahun Akademik (TA) 2015/2016 yang terdaftar di Akademi Kebidanan Ar Rum Salatiga dan Akademi Kebidanan Panti Wilasa YAKKUM Semarang.

2. Mahasiswa yang sudah pernah mendapatkan hasil belajar, baik ujian harian maupun ujian semester.
3. Bersedia menjadi responden dan telah mengisi Surat Pernyataan Persetujuan (PSP) untuk ikut serta dalam penelitian.

Kriteria eksklusi dalam penelitian ini adalah mahasiswa yang melakukan cuti akademik pada saat pelaksanaan penelitian.

\section{Rancangan Penelitian}

Rancangan penelitian yang digunakan dalam penelitian ini adalah action research (penelitian tindakan) dengan pre-post test design yang bertujuan menganalisis nilai karakter, dan motivasi belajar mahasiswa setelah penerapan gerakan karakter "SEHAT". Gerakan ini merupakan satu pohon penelitian untuk menilai karakter yang dilaksanakan di pendidikan kebidanan dengan 5 (lima) gerakan sebagai permulaannya yaitu gerakan pengungkapan nilai karakter, gerakan disiplin kampus, gerakan artikel dinding, gerakan olahraga, dan gerakan metamorfosa yang dilaksanakan oleh seluruh civitas akademik termasuk dosen dan tenaga kependidikan. Gerakan karakter "SEHAT" disusun oleh Tim Karakter yang terdiri dari 7 orang dengan mengadopsi kegiatan-kegiatan yang sudah ada di institusi pendidikan dan dilakukan modifikasi.

Tahapan rancangan penelitian ini sesuai dengan model action research dari Kemmis S dan Mc. Taggart, mulai dari perencanaan tindakan, pelaksanaan tindakan, observasi, dan refleksi dalam setiap siklusnya.

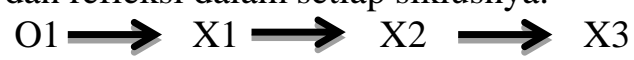

Keterangan :

O1 : Baseline dan pretest penerapan gerakan karakter "SEHAT"

$\mathrm{X} 1$ : Action resarch siklus 1

$\mathrm{X} 2$ : Action resarch siklus 2

$\mathrm{X} 3$ : Action resarch siklus 3

Penelitian ini dilaksanakan selama tiga siklus, 4 (empat) minggu untuk setiap siklusnya. Pengukuran pre test pada nilai karakter, dan motivasi belajar dilakukan sebelum penerapan gerakan karakter "SEHAT" dan disetiap akhir siklus (post test). Hasil post test di akhir siklus menjadi hasil pre test untuk siklus berikutnya. 
Hasil

Tabel 1 Peningkatan Nilai Karakter Sebelum dan Setelah Penerapan Gerakan Karakter "SEHAT"

\begin{tabular}{|c|c|c|c|c|}
\hline Nilai Karakter & $\begin{array}{c}\text { Pra Siklus } \\
(n=62)\end{array}$ & Siklus I (n=62) & Siklus II $(n=62)$ & $\begin{array}{c}\text { Siklus III } \\
(n=62)\end{array}$ \\
\hline \multicolumn{5}{|l|}{ Mandiri } \\
\hline Mean (SD) & $53,27 \pm 10,64$ & $54,39 \pm 9.90$ & $58,20 \pm 11,20$ & $65,99 \pm 11,23$ \\
\hline Median & 52,78 & 52,78 & 58,33 & 63,89 \\
\hline Rentang & $30,56-69,44$ & $36,11-83,88$ & $38,89-91,67$ & $44,44-94,44$ \\
\hline Nilai $p$ & & $0,294 * *$ & $0,021 * *$ & $0,000 * *$ \\
\hline Peningkatan pre - post & \multicolumn{4}{|c|}{$0,000 * *$} \\
\hline \multicolumn{5}{|l|}{ Tanggung Jawab } \\
\hline Mean (SD) & $63,12 \pm 11,09$ & $63,92 \pm 9,76$ & $68,17 \pm 11,71$ & $74,89 \pm 10,76$ \\
\hline Rentang & $30-90$ & $43,33-86,67$ & $43,3 \overline{3}-90$ & $50-96,67$ \\
\hline Nilai $p$ & & $0,452 *$ & $0,006^{*}$ & $0,000 *$ \\
\hline Peningkatan pre - post & \multirow{2}{*}{\multicolumn{4}{|c|}{$0,000 *$}} \\
\hline Kreatif & & & & \\
\hline Mean (SD) & $49,46 \pm 10,80$ & $52,33 \pm 9,94$ & $58,15 \pm 12,14$ & $64,43 \pm 12,12$ \\
\hline Median & 50,00 & $52, \overline{78}$ & $5 \overline{5,56}$ & 63,89 \\
\hline Rentang & $25-77,78$ & $33,33-77,78$ & $38,89-91,67$ & $38,89-97,22$ \\
\hline Nilai $p$ & & $0,021 * *$ & $0,000 * *$ & $0,000 * *$ \\
\hline Peningkatan pre - post & \multicolumn{4}{|c|}{$0,000 * *$} \\
\hline \multicolumn{5}{|l|}{ Kerja Keras } \\
\hline Mean (SD) & $60,01 \pm 14,02$ & $61,49 \pm 11,85$ & $66,33 \pm 14,64$ & $73,39 \pm 11,65$ \\
\hline Median & 58,33 & 58,33 & $6 \overline{6,67}$ & 75,00 \\
\hline Rentang & $29,17-91,67$ & $37,50-95,83$ & $41,67-100$ & $54,17-100$ \\
\hline Nilai $p$ & & 0,634 & 0,008 & 0,000 \\
\hline Peningkatan pre - post & \multicolumn{4}{|c|}{$0,000 * *$} \\
\hline Menghargai Prestasi & & & & \\
\hline Mean (SD) & $68,39 \pm 14,20$ & $69,14 \pm 13,01$ & $72,85 \pm 13,95$ & $78,28 \pm 12,76$ \\
\hline Median & 70,00 & 70,00 & 73,33 & 80,00 \\
\hline Rentang & $36,67-100$ & $43,33-100$ & $46,67-100$ & $40-100$ \\
\hline Nilai $p$ & & $0,881 * *$ & $0,011 * *$ & $0,002 * *$ \\
\hline Peningkatan pre - post & \multicolumn{4}{|c|}{$0,000 * *$} \\
\hline
\end{tabular}

Berdasarkan tabel 1, nilai-nilai karakter yang dikembangkan dalam gerakan mengalami peningkatan. Terdapat perbedaan rerata nilai karakter mandiri, tanggung jawab, kreatif, kerja keras dan menghargai prestasi $(p=0,000)$.

Tabel 2 Peningkatan Motivasi Belajar Mahasiswa

\begin{tabular}{lcccc}
\hline \multicolumn{1}{c}{ Variabel } & $\begin{array}{c}\text { Pra Siklus } \\
(\mathbf{n = 6 2})\end{array}$ & $\begin{array}{c}\text { Siklus I } \\
(\mathbf{n = 6 2})\end{array}$ & $\begin{array}{c}\text { Siklus II } \\
(\mathbf{n = 6 2})\end{array}$ & $\begin{array}{c}\text { Siklus III } \\
(\mathbf{n = 6 2})\end{array}$ \\
\hline Mean (SD) & $70,39 \pm 7,32$ & $72,80 \pm 6,27$ & $74,55 \pm 6,81$ & $78,96 \pm 6,95$ \\
Rentang & $52,26-85,95$ & $61,44-88,79$ & $59,79-88,10$ & $63,38-94,34$ \\
Peningkatan per siklus (\%) & \multicolumn{4}{c}{$\mathbf{0 , 0 0 0 *}$} \\
Peningkatan pre-post & \multicolumn{3}{c}{2,41} & $\mathbf{5 , 9 1}$ \\
\hline
\end{tabular}

Keterangan: *) Uji T tes berpasangan

Berdasarkan tabel 2 terdapat peningkatan di setiap siklus penelitian dan terdapat perbedaan rerata motivasi belajar sebelum dan sesudah Penerapan Gerakan Karakter "SEHAT". 
Tabel 3 Hasil Uji Korelasi antara Nilai-nilai Karakter (Gerakan Karakter "SEHAT" dengan Motivasi Belajar

\begin{tabular}{lccc}
\hline \multicolumn{1}{c}{ Uji Korelasi } & Nilai $\boldsymbol{p}$ & $\begin{array}{c}\text { Cooefision } \\
\text { Correlation }(\boldsymbol{r})\end{array}$ & $\begin{array}{c}\text { Cooefisien } \\
\text { Determination } \\
\left(\boldsymbol{r}^{2}\right)\end{array}$ \\
\hline Mandiri & $0,005^{* *}$ & 0,355 & 0,126 \\
Tanggung Jawab & $0,000^{*}$ & 0,576 & 0,332 \\
Kreatif & $0,003^{* *}$ & 0,369 & 0,136 \\
Kerja Keras & $0,000^{* *}$ & 0,509 & 0,259 \\
Menghargai Prestasi & $0,000^{* *}$ & 0,444 & 0,197 \\
Gerakan Karakter "SEHAT" dengan & $0,000^{*}$ & 0,594 & 0,353 \\
motivasi belajar & & &
\end{tabular}

Keterangan: *) Uji T tes berpasangan; **)Uji Wilcoxon

Berdasarkan tabel 3 terdapat korelasi positif antara motivasi belajar, nilai karakter mandiri, tanggung jawab, kreatif, kerja keras, dan menghargai prestasi. Demikian halnya dengan gerakan karakter "SEHAT" dan memiliki kekuatan korelasi sedang.

\section{Diskusi}

Hasil penelitian terlihat peningkatan persentase disetiap siklus pada masing-masing nilai karakter. Data nilai karakter mandiri, tanggung jawab, kreatif, kerja keras, menghargai prestasi dilihat dari rata-ratanya meningkat di setiap siklus. Peningkatan ratarata di setiap siklus sebagai dampak dari penelitian setiap siklus yang dilakukan perbaikan. Hasil uji beda nilai karakter mandiri, kreatif, kerja keras, dan menghargai prestasi yang bermakna antara sebelum dengan sesudah penerapan gerakan karakter "SEHAT".

Pada siklus I sampai dengan siklus III kendala terbesar dalam penerapan gerakan karakter "SEHAT" adalah waktu. Beberapa gerakan yang diawalnya sudah disepakati waktunya belum terlaksana secara maksimal. Kendala lain adalah adaptasi mahasiswa yang biasa monoton dengan kegiatan kampus sedikit berubah dengan adaya penerapan gerakan karakter "SEHAT" sehingga ada yang menyatakan sebagai suatu gangguan. Kendala lain adalah belum semua civitas akademik terlibat dalam tiap-tiap gerakan. Kendala yang terjadi disikapi peneliti dengan memberikan penjelasan kembali pentingnya gerakan untuk meningkatkan nilai karakter yang ada dalam diri mahasiswa sekaligus meningkatkan motivasi belajar mahasiswa. Memberikan motivasi dan semangat kepada mahasiswa dalam menerapkan setiap gerakan dan dalam kegiatan civitas akademik yang lain. Mengkoordinasikan jadwal kegiatan dengan bidang akademik dan ketua kelas.

Bermakna dan meningkatnya nilai-nilai karakter setelah penerapan gerakan karakter "SEHAT" membuktikan bahwa gerakan yang diawali dengan pengetahuan moral (kesadaran moral, pengetahuan nilai moral, penentuan perspektif, pemikiran moral, pengambilan keputusan, pengetahuan pribadi), berlanjut pada perasaan moral (hati nurani, harga diri, empati, mencintai hal yang baik, kendali diri, kerendahan hati), dan pada akhirnya menuju kepada tindakan moral (kompetensi, keinginan, kebiasaan) terkait dengan nilainilai karakter. Adanya proses intervensi (pembelajaran, pemodelan, dan penguatan) dan proses habituasi (pensuasanaan, pembiasaan, dan penguatan) pada akhirnya menjadi karakter yang melekat kepada yang melaksanakannya, yaitu mahasiswa. Nilainilai luhur yang terdapat di dalamnya akan terintegrasi melalui proses internalisasi dan personalisasi pada diri masing-masing individu melalui kedisiplinan, modeling dan diulang-ulangnya Gerakan Karakter "SEHAT".

Belum maksimalnya nilai-nilai karakter mahasiswa setelah penerapan gerakan karakter "SEHAT" dapat terjadi karena banyak faktor yang memengaruhi karakter seseorang. Pengaturan waktu yang belum maksimal pada diri mahasiswa menjadikan mereka dalam menyelesaikan tugas-tugas, baik di setiap gerakan maupun tugas perkuliahan terkadang asal jadi, belum maksimal secara berkualitas, dan penuh ketelitian. Kegemaran untuk membaca dan 
menulis, menularkan ide-ide kreatif ke sesama teman belum maksimal dilakukan. Mahasiswa masih belum konsisten dalam berperilaku, perilaku untuk selalu konsekuen terhadap segala sesuatu yang dilakukan, masih terpengaruh oleh orang lain dan kemampuan bekerja sendiri tanpa bantuan orang lain secara maksimal. Keinginan untuk mencari informasi yang terbaru terkait dengan perkuliahan, kegemaran menulis, dan membaca belum maksimal juga dilakukan. Kreatifitas mahasiswa dapat ditingkatkan dengan menambahkan dalam gerakan karakter "SEHAT pengekspresian diri mahasiswa melalui kegiatan seni yang selama ini belum maksimal dilaksanakan di institusi.

Proses pendidikan karakter pada latar mikro tidak sebatas integrasi dan pembiasaan di dalam kelas/sekolah saja, ada pembiasaan kehidupan keseharian di rumah yang menjadi salah satu faktor yang memiliki pengaruh terhadap karakter seseorang. Akhir penelitian 3 (tiga) siklus terkait dengan nilai karakter terlihat mulai berkembang, terbukti dalam pengamatan sudah memperlihatkan berbagai perilaku yang dinyatakan dalam indikator dan mulai konsisten. . $^{53,14}$

Gerakan karakter "SEHAT" apabila dilihat dari bentuknya merupakan salah satu bentuk kegiatan ekstrakurikuler yang terus dikembangkan proses pembiasaan dan penguatan dalam rangka pengembangan nilai/karakter. Ekstrakurikuler memiliki fungsi pengembangan, sosial, rekreatif, dan persiapan karir yang bertujuan mengembangkan potensi mahasiswa secara optimal dan terpadu, memantapkan kepribadian mahasiswa, mampu mengaktualisasikan potensi mahasiswa dalam pencapaian prestasi, dan menyiapkan mahasiswa menjadi warga masyarakat yang berkarakter baik. ${ }^{15,16}$

Penerapan gerakan karakter "SEHAT" membutuhkan komitmen yang besar dari seluruh civitas akademik dalam pelaksanaan. Pada saat satu elemen, misalnya dosen tidak mendukung adanya gerakan, memiliki pengaruh terhadap mahasiswa yang melaksanakan gerakan. Kehadiran dosen dan tenaga kependidikan memberikan energi positif yang meningkatkan semangat mahasiswa dalam mengikuti setiap kegiatan dan menumbuhkan motivasi yang tinggi dalam diri mahasiswa untuk melakukan perbuatan yang baik.

Penerapan gerakan karakter "SEHAT" dengan melibatkan seluruh civitas akademik ternyata menambah rasa kekeluargaan antara mahasiswa, dosen, dan tenaga kependidikan. Rasa kekeluargaan antar mahasiswa juga terjalin lebih dekat. Lagu gerakan karakter "SEHAT" memberikan makna/semangat tersendiri dalam diri mahasiswa untuk menginternalisasikan setiap kata-kata dalam lagu kedalam perilaku sehari-hari. Gerakan karakter "SEHAT" yang sudah dilaksanakan perlu dikembangkan berdasarkan minat, bakat, dan seni yang ada dalam diri mahasiswa untuk memaksimalkan nilai-nilai karakter.

Hasil penelitian menunjukkan bahwa motivasi belajar mahasiswa mengalami peningkatan di setiap evaluasi akhir siklus dari rata-rata sebelum penerapan gerakan karakter "SEHAT" 70,39 meningkat menjadi 78,96 pada akhir siklus III. Motivasi yang tinggi berdasarkan indikator motivasi pada mahasiswa bahwa belajar menjadi kebutuhan, memiliki keinginan berprestasi dari dalam diri sendiri, memiliki orientasi pada masa depan, memiliki minat dalam belajar, memiliki dorongan untuk berkompetisi, hukuman sebagai sarana memperbaiki diri, dan mengikuti kegiatan ekstrakurikuler dengan lebih bersemangat.

Perbedaan rerata motivasi belajar yang bermakna sebelum dan sesudah tiga siklus penerapan gerakan karakter "SEHAT". Penelitian yang dilakukan oleh Marvin Berkowitz (University of Missouri-St.Louis), menunjukkan adanya peningkatan prestasi akademik siswa pada sekolah-sekolah yang menerapkan pendidikan karakter, serta didukung adanya peningkatan motivasi intrinsik dan ekstrinsik siswa. Dalam Behavior Theory memandang motivasi sebagai suatu perubahan perilaku (respon). Perilaku melibatkan diri dalam tugas-tugas, bersikap gigih pada saat pengerjaan tugas, dan selalu berusaha merupakan penilaian yang dapat dilakukan oleh dosen dalam menilai peserta didik. ${ }^{6,10}$

Motivasi belajar yang tinggi terlihat dari diri mahasiswa, belajar sudah menjadi kebutuhan bukan lagi sebagai tuntutan dalam kuliah. Belajar menjadi prioritas dalam 
kegiatan sehari-hari mahasiswa, bukan hanya saat akan menghadapi ujian. Ada kemauan untuk belajar secara mandiri dalam mengejar ketertinggalan. Keinginan untuk berprestasi pun keluar dari dalam diri mahasiswa sendiri, bukan karena tuntutan orang tua atau pihak dari luar. Kebutuhan akan belajar sebagai upaya untuk meningkatkan prestasi mahasiswa, tidak sekedar mendapatkan gelar atau predikat "lulus" saja dan memiliki kesadaran bahwa belajar merupakan jalan untuk mendapatkan masa depam yang lebih baik. Memiliki minat dalam belajar dengan memiliki ketertarikan dalam mempelajari halhal yang baru, mengerjakan tugas dengan baik sesulit apapun dan penuh semangat serta mempergunakan setiap kesempatan untuk bertanya tentang hal-hal yang belum jelas dalam pembelajaran kepada dosen atau teman.

Dorongan dari luar terkait motivasi belajar mahasiswa juga memiliki daya dukung yang baik. Adanya dorongan untuk berkompetisi secara sehat sehingga mendapatkan pengakuan mahasiswa berprestasi, hadiah yang didapatkan oeh mahasiswa menjadi pemacu dalam belajar tetapi bukan menjadi satu-satunya tujuan untuk belajar merupakan faktor dari luar yang memiliki pengaruh dalam memotivasi mahasiswa untuk belajar. Faktor lain di antaranya konsekuensi atas sanksi yang diterima sebagai sarana memperbaiki diri dan bersikap arif apabila mendapatkan teguran baik dari dosen maupun teman. Semboyansemboyan yang ada di kampus mampu memotivasi mahasiswa untuk giat belajar, dan dalam kondisi seperti apapun dapat memanfaatkan waktu untuk belajar.

Hasil penelitian juga menunjukkan bahwa terdapat korelasi positif antara nilai-nilai karakter (mandiri, tanggung jawab, kreatif, kerja keras dan menghargai prestasi) dan motivasi belajar dengan kekuatan korelasi sedang. Kekuatan korelasi terkuat adalah nilai tanggung jawab dengan $\mathrm{r}=0,576$ dan $p=0,000$. Secara umum rata-rata nilai karakter yang mewakili gerakan karakter "SEHAT" berkorelasi positif dengan motivasi belajar yaitu berkekuatan korelasi sedang.

Motivasi belajar perlu dimiliki oleh peserta didik khususnya dalam menunjang prestasi belajar. Hal ini harus ditekankan serta ditumbuhkan dari faktor intrinsik atau faktor yang berasal dari dalam diri peserta didik dengan cara menumbuhkan karakter yang baik dalam belajar. Karakter yang baik ini, di antaranya adalah disiplin dalam mengerjakan tugas yang diberikan dosen, kerja keras, dan pantang menyerah dalam menyelesaikan tugas, kreatif dan inovatif, mandiri, mempunyai rasa ingin tahu yang besar, menghargai prestasi, gemar membaca, dan memiliki rasa tanggung jawab terhadap tugastugas yang diberikan.

Penanaman nilai-nilai karakter mendorong mahasiswa untuk nyaman belajar karena situasi bersahabat, suasana damai muncul pada saat diskusi, namun demikian siswa mempunyai tanggung jawab dalam menyelesaikan tugas dengan baik dan sesuai aturan yang diberikan serta jujur dalam mengerjakan tes, perasaan menjadi tenang karena selama tes tidak ingin menyontek dan tidak ingin bertanya kepada teman. Sikap dan perilaku yang tidak mudah tergantung pada orang lain dalam menyelesaikan tugas-tugas, memiliki kepercayaan diri dalam memecahkan masalah. Bersikap dan berperilaku atas dasar inisiatif dan kemampuan sendiri. Segala pekerjaan yang dapat dikerjakan sendiri dilakukannya dengan penuh tanggung jawab. Dalam kemandiriannya ada motivasi untuk selalu melakukan yang terbaik (paling tidak pertama-tama untuk dirinya sendiri). Kemandirian sebagai bentuk perilaku mampu mengaktualisasikan diri sebagai suatu kebutuhan dasar yang dibawa oleh individu demi meningkatkan kemampuan individu dan memunculkan diri sebagai pribadi yang berprestasi. ${ }^{17,18}$

Nilai tanggung jawab yang harus dimiliki oleh mahasiswa merupakan sikap dan perilaku seseorang untuk melaksanakan tugas dan kewajibannya, yang seharusnya dia lakukan, terhadap diri sendiri, masyarakat, lingkungan (alam, sosial dan budaya), negara, dan Tuhan Yang Maha Esa. ${ }^{14,17-19}$ Mahasiswa yang memiliki kreatifitas tinggi mampu melakukan sesuatu yang menghasilkan cara atau hasil baru dari yang telah dimiliki. Dapat diartikan juga memiliki daya cipta untuk menemukan/menciptakan sesuatu yang baru. ${ }^{17,}{ }^{20}$ Memiliki sikap pantang menyerah dalam memacu daya tahan kerja. Daya tahan kerja diartikan sebagai perilaku yang 
menunjukkan upaya sungguh-sungguh dalam mengatasi berbagai hambatan belajar, tugas dan menyelesaikan tugas dengan sebaikbaiknya. ${ }^{7,17,18,21,22}$ Serta memiliki sikap dan tindakan yang menolong dirinya untuk menghasilkan sesuatu yang berguna bagi masyarakat, mengakui dan menghormati keberhasilan orang lain. ${ }^{13,17,18}$

Motivasi mahasiswa diperlihatkan dengan partisipasi dan aktifnya dalam mengikuti kegiatan-kegiatan dalam proses pembelajaran. Membangkitkan motivasi belajar mahasiswa sangat penting, merangsang mahasiswa menggunakan potensi-potensi yang dimiliki secara konstruktif dan produktif untuk mencapai tujuan yang merupakan kebutuhan. Motivasi belajar yang dimiliki oleh mahasiswa mampu membangkitkan, meningkatkan dan memelihara semangat untuk tetap belajar hingga mencapai keberhasilan yang dicita-citakan.

\section{Simpulan}

1. Terdapat peningkatan nilai karakter mandiri, tanggung jawab, kreatif, kerja keras dan menghargai prestasi mahasiswa Diploma III Kebidanan setelah penerapan gerakan karakter "SEHAT".

2. Penerapan gerakan karakter "SEHAT" meningkatkan motivasi belajar mahasiswa Diploma III Kebidanan.

3. Terdapat korelasi antara nilai karakter mandiri, tanggung jawab, kreatif, kerja keras, menghargai prestasi dengan motivasi belajar mahasiswa Diploma III Kebidanan.

\section{Daftar Pustaka}

1. Hermanto. D. Pengaruh Persepsi Mutu Pelayanan Kebidanan terhadap Kepuasan Pasien Rawat Inap di RSUD Dr. H.Soemarno Sosroatmojo Bulungan Kalimantan Timur. Jurnal Penelitian Kesehatan Suara Forikes. 2012;3:60-8.

2. Husna A. Kinerja Bidan di Desa dalam Program Jaminan Pemeliharaan Kesehatan Masyarakat Miskin. Jurnal Kesehatan Masyarakat Nasional. 2009;4:18-25.

3. Titaley CR, Hunter CL, Dibley MJ, Heywood P. Why do Some Women Still Prefer Traditional Birth Attendants and Home Delivery?: A Qualitative Study on Delivery Care Services in West Java Province, Indonesia. BMC pregnancy and childbirth. 2010;10:43.

4. Pramono MS, Sadewo FXS. Analisis Keberadaan Bidan Desa dan Dukun Bayi di Jawa Timur. Buletin Penelitian Sistem Kesehatan. 2012;15:305-13.
5. Susilowati. E, Mudy Oktiningrum, Niluh Nita Silfia, Desy Widyastutik, Hapsari Windayanti. Preliminary Studies. Semarang: (Dalam: Workshop Nasional Gerakan Pengembangan Karakter Dosen Kebidanan dalam Upaya Peningkatan Kompetensi Mahasiswa di Institusi Kebidanan), 2014.

6. Slavin. RE. Psikologi Pendidikan: Teori dan Praktik. Sarwiji. B, editor. Jakarta: Indeks; 2011. 96-9 p.

7. Ramadhani. A. Pengaruh Pendidikan Karakter terhadap Motivasi Belajar. Counselium. 2013;1(2):9-16

8. Boekaerts. M. Motivation to Learn. Walberg HJ, editor. Chicago: IBE Publication Unit The International Academy Education; 2002. 14 p.

9. Brophy. J. Motivating Students to Learn. Second ed. New Jersey: Lawrence Erlbaum Associates Publishers; 2004. 3-11 p.

10. Schunk. DH, Paul R. Pintrich, Judith L. Meece. Motivation in Education: Theory, Research, and Applications. New Jersey: Pearson Education, Inc; 2012. 6-8,16-24,9-37,53-8,65-75,231-64,358-407 p.

11. Berkowitz. MW, Melinda C. Bier. What Works in Character Education. Journal of Research in Character Education. 2007;5(1):29-48.

12. Top. N. Character Education for Academic Achievement. Fountain Magazine. 2012.

13. Hartoyo. I. Pengintegrasian Pilar-Pilar Pendidikan Karakter dalam Proses Pembelajaran di Perguruan Tinggi. Medan: Universitas Negeri Medan; 2013.

14. Lickona. T. Educating for Character: How Our Schools Can Teach Respect and Responbility. New York City: Bantam Books; 1991. 60-165 p.

15. Budimansyah. D. Perancangan Pembelajaran Berbasis Karakter. Bandung: Widya Aksara Press; 2014. 5-6 p.

16. Supriatna. M. Pendidikan Karakter Melalui Ekstrakurikuler. Bandung: Universitas Pendidikan Indonesia; 2010.

17. Fathurrohman. P, AA Suryana, Fatriany F. Pengembangan Pendidikan Karakter. Aep Gunarsa, editor. Bandung: Refika Aditama; 2013. 106-12 p.

18. Kementerian Kesehatan Republik Indonesia. Rencana Induk Pengembangan Pendidikan Karakter Bangsa. Jakarta: Kementerian Kesehatan Republik Indonesia; 2010.

19. Siburian. P. Penanaman dan Implementasi Nilai Karakter Tanggung Jawab. The Character Building University of Medan. 2011:14-6.

20. Ginanjar. A. Pengembangan Karakter Rasa Ingin Tahu dalam Pembelajaran IPS Melalui Strategi Pembelajaran Inkuiri Sosial di Kelas VII E SMP Pasundan 6 Bandung. Bandung: Universitas Pendidikan Indonesia; 2013.

21. Patmawati. D, Rahmah Johar, Tuti Zubaidah. Pembelajaran Segitiga dengan Pendekatan Kontekstual Berbasis Karakter di Kelas VII SMP Negeri 3 Banda Aceh Tahun Ajaran 2012/2013. Jurnal Pendidikan Matematika PARADIKMA. 2013;6(2):120-30.

22. Ikhwanudin. Implementasi Pendidikan Karakter Kerja Keras dan Kerjasama dalam Perkuliahan. Jurnal Pendidikan Karakter. 2112;2(2):153-63. 
Endang Susilowati: Penerapan Gerakan Karakter Sejuk Emosi, Hati, Akal, dan Tubuh (SEHAT) untuk Meningkatkan Motivasi Belajar Mahasiswa Diploma III Kebidanan 